\title{
The Reception of Olga Tokarczuk's Flights in the English Language Press
}

\section{Recepcja Biegunów Olgi Tokarczuk w anglojęzycznej prasie}

On May 22, 2018, Olga Tokarczuk along with translator Jennifer Croft won the Man Booker International Prize for the English translation of the former's novel Flights. Tokarczuk became the first Polish writer to win this prestigious award, whose previous recipients include such literary household names as Philip Roth, Ismail Kadare, and Chinua Achebe. In writing this article, I have analyzed several reviews of Flights in leading American and British newspapers to identify common themes. Like Polish reviewers in 2007, English language reviewers in 2017 and 2018 have praised the novel for its successful transcending of the conventional limitations of form. However, whereas Polish reviewers have emphasized the book's metaphysical implications, they were ignored by English language reviewers, who instead have emphasized Flights' - and, more broadly, Tokarczuk's - anti-nationalism, a theme more politically relevant today than when Flights was initially published in Poland.

Flights is a collection of approximately one hundred vignettes with one common theme: travel. The original Polish title, Bieguni, refers to a fictional sect of Russian Orthodox Old Believers who, like the Gnostics or the Manicheans, believe that the material world is evil. The Bieguni further are convinced that humans are most susceptible to evil when they remain physically in place, and so they constantly travel. The stories gathered in Flights are both fictional (such as that of a Polish man who becomes separated from his family on holiday in Croatia; pp. 24-52) and based on historic fact (including the transportation of Frederic Chopin's heart from France to Warsaw by the composer's devoted sister Ludwika; pp. 312 321). The book was a major success in Poland, selling 170,000 copies and 
winning the Nike Award, arguably contemporary Poland's most coveted literary prize. ${ }^{1}$

A full decade separated the publication of the initial Polish translation of Flights and its English translation. Bieguni was first published in Polish in 2007, while Jennifer Croft's translation appeared in Great Britain in 2017 and in the United States one year later. Thus although there are certain similarities in the reception of the book in Poland, on the one hand, and in Britain as well as the United States, on the other, the political and social changes that have occurred over that decade have added a new dimension to the reception of the English translation of the book.

With regards to similarities, both Polish and English language reviewers note that Tokarczuk is an iconoclast, and that Flights cannot be easily pigeonholed into one literary genre. In her review of the book in Polityka, Marta Czuber writes that Flights is a book "that sometimes wants to be a novel, and at other times wants to be a treatise." Cuber claims that Tokarczuk's transcending of genre is coherent and readable, noting that "the foreignness and resistance the reader has to deal with while reading this book (...) decline over time." Similarly, Dariusz Nowacki's review in Tygodnik Powszechny noted that Flights is "[a] book, a work, but not really a novel," adding that it is a "textual hybrid" like Tokarczuk's earlier book, House of Day, House of Night. He comments that Tokarczuk's novel approach to literature "is from beginning to end a thought-out construction, almost a monograph." 3 Tokarczuk's unconventional form of narrative is also picked up by Andrzej Franaszek in his review of Flights for Gazeta Wyborcza: "[Tokarczuk] creates a new form, which she herself calls a 'constellation novel' which is supposed to correspond to our experiences. Not a linear narrative form, but a collection of diverse journal entries, short notes, philosophical investigations, and short stories is the appropriate literary form for it." ${ }^{4}$

Tokarczuk's transcending of traditional literary forms has been widely praised by English language reviewers as well. In fact, this was one of the main reasons why the novel gained recognition in the English language world. When presenting Tokarczuk the Man Booker International Prize, Lisa Appignanesi, the chair of the jury, said: "[Flights] isn't a traditional narrative. (...) We loved the voice of the narrative - it's one that moves from wit and gleeful mischief to real emotional texture and has the ability to create character very quickly, with interesting digression and speculation." 5

1 A. Flood, “Olga Tokarczuk's Extraordinary 'Flights' Wins Man Booker International Prize," The Guardian, 22.05.2018, https://www.theguardian.com/books/2018/may/22/olga-tokarczuk-flights-wins-man-booker-international-prize-polish, accessed: 27.08.2018.

2 M. Czuber, "Podróżuję, więc jestem," Polityka, 13.10.2007, no. 41 (2624), p. 105.

${ }^{3}$ D. Nowacki, "Podróżowanie jest koniecznością," Tygodnik Powszechny, 9.10.2017, https:// www.tygodnikpowszechny.pl/podrozowanie-jest-koniecznoscia-138350, accessed: 27.082018.

4 A. Franaszek, "Wezwanie niepokoju," Gazeta Wyborcza, 16.10.2007, no. 242 (5550), p. 14.

5 A. Flood, op. cit. 
However, while English language reviewers do note Tokarczuk's unique approach to genre, they nonetheless generally refer to it as a novel. Although in his review of Flights in the New York Times Parul Sehgal calls the book a "novel," he also notes that it is "transhistorical, transnational; it leaps back and forth through time, across fiction and fact," noting that the stories contained in the volume "often have the flavor of case studies." This is echoed in the Publisher's Weekly review of Flights, whose author notes calls it a "discursive novel" and "a cacophony of voices." Like Andrzej Franaszek, the author believes that Flights" disjointed style ultimately is successful: "The threads ultimately converge in a remarkable way, making this an extraordinary accomplishment." The Guardian's Kapka Kassabova, meanwhile, writes that Tokarczuk writes in the "continental tradition of the 'thinking' or essayistic novel," comparing her to, like the Publisher's Weekly review, to W.G. Sebald, but also to Milan Kundera and Dubravka Ugrešić, among others. ${ }^{8}$ In the Los Angeles Review of Books, Eileen Battersby similarly compares Tokarczuk to Sebald and calls Flights a "sui generis novel," again implying its novelty in terms of form and genre.?

Since the initial Polish publication of Flights, there has been a rise in xenophobia and anti-immigrant sentiment in both the United States and Europe. These themes are completely omitted in the Polish reviews discussed here, but English language reviewers have noted them. Parul Sehgal suggests that the notion of travel within the context of open borders makes Flight relevant in a way it was not when it was first published in Poland. "This novel was written in a simpler time, the author has said, more than ten years ago, before nationalist movements and violent xenophobia erupted again in Europe. Totalitarianism seems safely in the past in this book, the movement of people a natural right," he writes. ${ }^{10}$

Whereas Polish reviewers did not mention the disturbing story of an African man killed, stuffed, and kept by an Austrian emperor as a decoration chronicled in Flights (pp. 141-167), it is noted by Sehgal, Battersby, and Kassabova. The latter reviewer does not explicitly mention the rise of nationalism and racism, her review also includes a quote by Tokarczuk that Jews and Gypsies were

${ }^{6}$ P. Sehgal, "Fables Leap Back and Forth Through Time in 'Flights,"” New York Times, 14.08.2018, https://www.nytimes.com/2018/08/14/books/review-flights-olga-tokarczuk.html, accessed: 27.08.2018.

7 “Flights," Publisher's Weekly, https://www.publishersweekly.com/978-0-525-53419-8, accessed: 27.08.2018.

${ }^{8}$ K. Kassabova, “'Flights' by Olga Tokarczuk Review - The Ways of Wanderers," Guardian, 3.06.2017, https://www.theguardian.com/books/2017/jun/03/flights-by-olga-tokarczuk-review, accessed: 27.08.2018).

9 E. Battersby, "Complex Harmonies: On Olga Tokarczuk's 'Flights," Los Angeles Review of Books, 11.04.2018, https://lareviewofbooks.org/article/complex-harmonies-on-olga-tokarczuks-flights, accessed: 27.08.2018.

${ }^{10}$ P. Sehgal, op. cit. 
persecuted by "tyrants of all stripes, infernal servants" because of their itinerant lifestyle. ${ }^{11}$ Thus, like Sehgal, Kassabova implies a correlation between racism and the limiting of the free movement of peoples as a major theme of the book.

Tokarczuk's opposition to nationalism, both in Flights and in general, was also emphasized in the English language press's coverage first of Tokarczuk's nomination for the Man Booker International Prize and, later, her winning the award. In particular, her opposition to anti-Semitism in Polish history and the hostile reaction to her statements on this topic on the part of nationalists were noted. One month before Tokarczuk won the Man Booker International Prize, the Guardian published an interview with the novelist in which the latter said she was "naïve" for thinking that Poles could deal with dark areas in their history and noting that she was called a "targowiczanin" (which the author of the article translates as "traitor") by her compatriots. ${ }^{12}$ Meanwhile, when Tokarczuk won the award, Anna Codreo-Rado of The New York Times wrote that Tokarczuk "drew ire from nationalist critics and she received death threats" for her previous statements that Poles have a difficult time with coming to grips with dark chapters related to the history of Polish-Jewish relations. ${ }^{13}$ Tokarczuk's opposition to anti-Semitism and particularly her unsentimental take on Polish-Jewish relations in the past in her novel The Books of Jacob (whose English translation will be published in 2019), which deals with the Frankists, a Messianic Jewish sect born in Poland in the eighteenth century, were also noted in two leading English language Israeli publications, the Times of Israel and Jerusalem Post. ${ }^{14}$

If Polish reviewers did not take note of the issue of racism and nationalism in their assessments of Flights, English language reviewers, unlike their Polish peers, have been largely deaf to the novel's metaphysical, quasi-religious undertones. Some of the latter have noted that while Flights' worldview is far from traditional religious orthodoxy, it affirms man's search for the transcendent. Marta Czuber claims that "although Olga Tokarczuk's prose is secular and far-removed from religious ideology, it is at the same time very sacral in

11 K. Kassabova, op. cit.

12 C. Armitstead, "Olga Tokarczuk: 'I Was Very Naïve. I Thought Poland Would Be Able to Discuss the Dark Areas of Our History," The Guardian, 20.04.2018, https:/www.theguardian. com/books/2018/apr/20/olga-tokarczuk-interview-flights-man-booker-international, accessed: 29.08.2018).

13 A. Codrea-Rado, "Olga Tokarczuk of Poland Wins Man Booker," The New York Times, 22.05.2018, https://www.nytimes.com/2018/05/22/books/booker-international-winner-olga-tokarczuk.html, accessed: 29.08.2018).

${ }^{14}$ H. Hacohen, " $1^{\text {st }}$ Polish Writer to Win Man Booker Prize Writes on Polish-Jewish Themes," The Jerusalem Post, 23.05.2018, https:/www.jpost.com/Diaspora/First-Polish-writerto-win-Man-Booker-prize-has-odd-relationship-with-Jews-558196, accessed: 29.08.2018; B. Osser, "Polish Winner of Man Booker Prize Chronicles Little-Known Jewish Sect's History," Times of Israel, 23.05.2018, https://www.timesofisrael.com/polish-winner-of-man-booker-prizechronicles-little-known-jewish-sects-history/, accessed: 29.08.2018. 
the old, deep meaning [of the word]. It convinces the reader that the feeling of the order of the universe is accessible to all who travel." ${ }^{15}$ Meanwhile, Andrzej Franaszek considers "human unbuckling between the body and God" to be one of the main themes of Flights. ${ }^{16}$

By contrast, English language reviewers have not noted the metaphysical aspects of Flights. In fact, when discussing the existential preoccupations of the novel, Kapka Kassabova reduces them to the physical, mundane, and visceral: "central recurring tropes are physical movement, the mortal body and the meaning of home." 17

Unlike many other Polish novels, Flights deals with travel, a universal theme that is not esoteric to readers not steeped within a hermetic Polish context. Even if the stories narrated by Tokarczuk take place in Poland (such as the transportation of Chopin's heart from Paris to Warsaw), the Polish setting is more the background than the main subject of the narrative. While travel is a frequent theme in fiction, from the early picaresque novels to the more modern "road trip" genre synonymous with the likes of Jack Kerouac and Hunter S. Thompson, Flights is unique in that travel is not the work's narrative vehicle so much as it is a metaphysical meditation on travel as a broader phenomenon itself. In an increasingly globalized world, the theme of travel is more relevant than ever before, hence the book's transcontinental appeal.

Because travel is a very multifaceted phenomenon, there are different aspects of travel that can pique readers' interest. Apart from the fact that a full decade separated Flights' initial Polish publication and that of its English translation, during which the anti-immigrant right has grown in power on both sides of the Atlantic, the fact that Polish and Anglophone reviewers have emphasized different aspects of the novel likely results from cultural differences. As both Britain and the United States are multicultural societies, the anti-nationalist and anti-racist flair of the book is more relevant than in Poland, which, while experiencing a growth in immigration in recent years, ${ }^{18}$ is still largely a homogenous society (and was even more homogenous in 2007). Furthermore, Polish reviewers' greater attentiveness to the metaphysical and quasi-religious accents is probably a reflection of the fact that rates of religious observance are higher and Poland, and so Polish reviewers are naturally more interested in the transcendent. ${ }^{19}$

${ }^{15}$ M. Czuber, op. cit., p. 105.

${ }_{16}$ A. Franaszek, op. cit.

${ }^{17}$ K. Kassabova, op. cit.

18 See: M. Piotrowska, "Do Polski przybywa coraz więcej imigrantów. UDSC przedstawia rekordowe dane," Polska the Times, 18.07.2017, https://polskatimes.pl/do-polski-przybywacoraz-wiecej-imigrantow-udsc-przedstawia-rekordowe-dane/ar/12280612, accessed:31.08.2018.

19 O. Smith, "Mapped: The World's Most (and Least) Religious Countries," The Telegraph, 14.01.2018, https://www.telegraph.co.uk/travel/maps-and-graphics/most-religious-countries-in-the-world/, accessed: 31.08.2018. 
In conclusion, Flights' success both in her native Poland and in the English speaking countries, her winning of both the Nike Award and the Man Booker International Prize, is evidence that the novel is a universal one. In particular, both Polish and American and British reviewers have praised the book for not being written in a way that can be confined into rigid categories yet at the same time being coherent and readable. The passage of time and changing political and social events have caused English speaking reviewers to interpret the book as a work standing in firm opposition to nationalism and Tokarczuk as an anti-nationalist, an aspect of the work that was lost on Polish reviewers. The latter, however, have noted its metaphysical, quasi-religious implications, something that English language reviewers have ignored or even denied.

\section{Bibliography}

Armitstead C., "Olga Tokarczuk: 'I Was Very Naïve. I Thought Poland Would Be Able to Discuss the Dark Areas of Our History,'” The Guardian, 20.04.2018, https://www.theguardian.com/books/2018/apr/20/olga-tokarczuk-interview-flights-man-booker-international, accessed: 29.08.2018.

Battersby E., "Complex Harmonies: On Olga Tokarczuk's 'Flights," Los Angeles Review of Books, 11.04.2018, https://lareviewofbooks.org/article/complex-harmonies-on-olga-tokarczuks-flights/, accessed: 27.08.2018.

Codrea-Rado A., "Olga Tokarczuk of Poland Wins Man Booker," The New York Times, 22.05.2018, https://www.nytimes.com/2018/05/22/books/bookerinternational-winner-olga-tokarczuk.html, accessed: 29.08.2018.

Czuber M., "Podróżuję, więc jestem," Polityka, 13.10.2007, no. 41 (2624).

"Flights," Publisher's Weekly, https://www.publishersweekly.com/978-0-525-534198, accessed: 27.08.2018.

Flood A., "Olga Tokarczuk's Extraordinary 'Flights' Wins Man Booker International Prize," The Guardian, 22.05.2018, https://www.theguardian.com/ books/2018/may/22/olga-tokarczuk-flights-wins-man-booker-international-prize-polish, accessed: 27.08.2018.

Franaszek A., "Wezwanie niepokoju," Gazeta Wyborcza, 16.10.2007, no. 242 (5550). Hacohen H., "1 $1^{\text {st }}$ Polish Writer to Win Man Booker Prize Writes on Polish-Jewish Themes," The Jerusalem Post, 23.05.2018, https://www.jpost.com/Diaspora/First-Polish-writer-to-win-Man-Booker-prize-has-odd-relationshipwith-Jews-558196, accessed: 29.08.2018.

Kassabova K., "Flights' by Olga Tokarczuk Review - The Ways of Wanderers," Guardian, 3.06.2017, https://www.theguardian.com/books/2017/jun/03/ flights-by-olga-tokarczuk-review, accessed: 27.08.2018. 
Nowacki D., "Podróżowanie jest koniecznością," Tygodnik Powszechny, 9.10.2017, https://www.tygodnikpowszechny.pl/podrozowanie-jest-koniecznoscia138350, accessed: 27.08.2018.

Osser B., "Polish Winner of Man Booker Prize Chronicles Little-Known Jewish Sect's History," Times of Israel, 23.05.2018, https:/www.timesofisrael.com/ polish-winner-of-man-booker-prize-chronicles-little-known-jewish-sectshistory/, accessed: 29.08.2018.

Piotrowska M., "Do Polski przybywa coraz więcej imigrantów. UDSC przedstawia rekordowe dane," Polska the Times, 18.07.2017, https://polskatimes.pl/do-polski-przybywa-coraz-wiecej-imigrantow-udsc-przedstawia-rekordowe-dane/ ar/12280612, accessed: 31.08.2018.

Sehgal P., "Fables Leap Back and Forth Through Time in 'Flights,"” New York Times, 14.08.2018, https://www.nytimes.com/2018/08/14/books/review-flights-olgatokarczuk.html, accessed: 27.08.2018.

Smith O., "Mapped: The World's Most (and Least) Religious Countries," The Telegraph, 14.01.2018, https://www.telegraph.co.uk/travel/maps-and-graphics/ most-religious-countries-in-the-world/, accessed: 31.08.2018.

Tokarczuk O., Flights, trans. J. Croft, New York 2018. 